\title{
University Students' Attitudes Towards Gender Roles Predicting Their Value Orientation
}

\author{
Ömer Faruk Çimen \\ Ministry of National Education, Elazı $\breve{g}$, Turkey \\ ORCID: 0000-0002-8066-2121
}

\author{
Nergüz Bulut Serin * \\ Department of Guidance and Psychological Counseling, Dr Fazıl Küçük Faculty of \\ Education, European University of Lefke, Lefke, Northern Cyprus
}

ORCID: 0000-0002-2074-3253

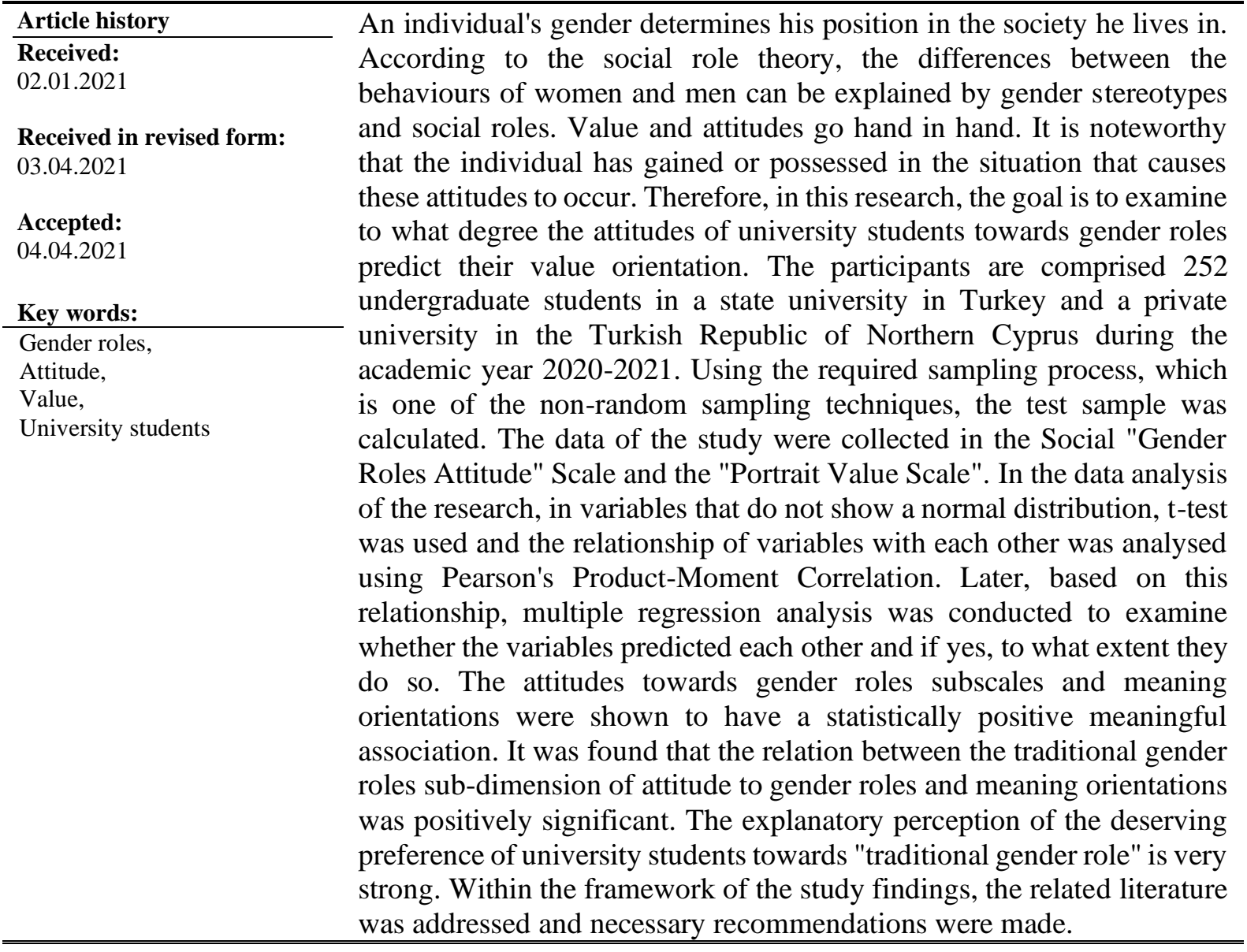

*Correspondency: nserin@eul.edu.tr 


\section{Introduction}

Gender is identified as all the habits, roles, conditions and duties of social and cultural movement that are necessary in a society regardless of one's biological sex (Zeyneloğlu, 2008). It needs men to review their traditional male identities, cultivate new habits, and reshape their relationships with women to create a culture focused on gender equality (Connell, 2016). Gender is just a means of emphasizing the societal roots of the subjective roles of men and women (Scott, 2007). While there are certain gender-specific traits, the role of society assigned to the person will vary over time (Gümüşoğlu, 2008). Gender refers to people's perceptions of the individual or the positions given to the individual by society according to the individual's biological characteristics (Vatandaş, 2007). Gender should not apply to the anatomical features that allow men and women to vary, but to the social characteristics of men and women (Giddens, 2008).

There are multiple scientific viewpoints on gender roles. Gender theories show the viewpoints on the distribution of positions that underlie gender inequalities (Keskin \& Ulusan, 2016). The psychoanalytic theory of Freud is based on the fact that the human actions cannot be described by cognitive mechanisms alone, but the subconscious must also be investigated by psychology (Yapıcıoğlu Ayaz, Kıvanççı, \& Safarov, 2019). It is one of the first scientific examples of gender development. Biological Hypothesis maintains that in the shaping of actions, biological features are decisive and it implies that different male and female brain systems induce different cognitive functions (Çıtak, 2008). The theory of social learning centers on the thesis that gender-related social roles are distinct and that interpersonal gender differences emerge from these multiple social roles. Neither women nor men have natural traits, with the lessons in the process of socialization the distinction occurs (Bussey \& Bandura, 1999; Schmitt, 2003). According to the Interactive Model, the gender-related behaviors of individuals are dictated by the personal decisions, desires and behaviors of others (Deaux \& Major, 1987). In other words, it implies that several variables influence gender-related social activities, that they are versatile and that they rely on the context (Dökmen, 2018). The hypothesis suggests that through socialization, gender roles are acquired later. It retains more control for/on the part of women (Deikman, Eagly, \& Kulesa, 2002).

Determining attitudes towards gender roles would lead to the introduction into the university's material of a more feminist viewpoint (Zeyneloğlu \& Terzioğlu, 2011). Males and females are specifically segregated from each other in a system that varies from culture to culture, and men gain a preference role over women (Ridgeway and Smith-Lovin, 1999). As a product of power dynamics in multiple dimensions, gender inequality arises from the understanding of men and women by society (Akın \& Demirel, 2003). The inherent disparities between males and females are not the explanation for the development of the idea of gender discrimination. As a matter of fact, the definition of inequality does not contain these disparities. Unfairness is not inherent, it is needless and unequal disparities that can be prevented, according to Şimşek (2011). Racial disparity is embedded in the perceptions of women and men in society. For example, when the woman makes the same attempt, a man is accused of leaving home, while the fact that he joins the company life to carry bread to the house transforms into strength and dignity (Lagrave, 1992).

With the modernization process, especially with women's obtaining the right to work and the increase in the level of education have led to significant changes in the roles and value that gender assumes (Seçgin, 2012). The individual's gender determines his position in the society he lives in. Gender effects are seen in different dimensions of life, starting with parents' upbringing the child (Baki, 2019). It can be said that gender duties limit women and men in 
certain areas (Geçici, Göllüce, Güvenç, \& Çelik, 2017). According to the social role theory, the differences between the behaviours of women and men can be explained by gender stereotypes and social roles.

Social role is the learned reactions that are defined by the society and expected from individuals in a social group (Dökmen, 2018). It is necessary to consider the transformations that can lead to the change of gender roles at both cultural and socio-economic levels. He stated that it would not be possible to assume that gender equality can be achieved only by trying to improve the position of women in existing social relations (Buğra, 2015). In the society, gender is the sum of differences created by social life rather than the differences that men and women acquire from birth. Differences that are not acquired by birth and attributed to the individual by society and culture are not universal and hence vary (Kaçar, 2007). Gender is a multidimensional concept aimed at explaining the values, judgments and roles of women and men regarding how they are perceived and evaluated by the society and the behaviors expected from these two (Altınova \& Duyan, 2013).

Changes in social life, changes in family and work area, increased number of working mothers, are amongst the changes in social roles (Batga, 2014). The gender roles that an individual learns are the main variables affecting his life and his relationships with other people and are functional in all stages of the individual's life (İmamoglu, 2008). Krahe (2018), for instance, expresses violence and discrimination against women as a social structure based on a social consensus about the roles and rights of women and men. The fact that women face many difficulties in business life and the restriction of their economic freedom are actually based on traditions and moral rules (Çıtak, 2008). In the context of gender roles, individuals learn to be a girl and a boy (Kalaycı \& Hayırsever, 2014). Thus, the behavior, attitude and knowledge levels of women and men are shaped in line with these expectations. While these expected differences from individuals increase in the period of masculinity, they become more pronounced in university life (Çıtak, 2008).

In the literature on gender roles, there are studies dealing with the gender equality of women. Alptekin (2019) found in his research with university students that female pre-service teachers attach more importance to equality than male pre-service teachers. Gui (2019) found in his study at a Chinese university that women have more gender-equal views than men, and in the study conducted by Schroeder, Bamaca-Colbert and Robins (2019) with a student of Mexican origin, it was found that although both girls and boys tend towards egalitarian gender role attitudes throughout adolescence, girls show more egalitarian attitudes than boys. Takkin (2020) found that university students have a high level of egalitarian attitudes and selfconfidence regarding gender roles.

According to a study conducted with the participation of teacher candidates, it was determined that female teacher candidates attach more importance to equality than male teacher candidates (Alptekin, 2019). In a study in which associate degree students participated, it was found that there is an egalitarian structure towards gender roles among female and male students, but male students are less egalitarian than female students (Güzel, 2016). In research involving university students, the attitudes of female students were more egalitarian than male students and it is concluded that male students have more traditional gender roles attitudes (Öngen \& Aytaç, 2013).

In another study conducted with university students, it was found that male students' gender perception is lower than female students, that is, gender perception changes according to the 
individual's gender (Özpulat \& Özvarış, 2018). Daşl1 (2019) discovered that university students have egalitarian gender attitudes and that the sum of women's attitudes toward gender roles is greater than that of men. Dursun (2020) stated that gender and attitudes toward violence against women vary by gender, and that gender perception explains attitudes toward violence against women; they also stated that an egalitarian view of gender roles should be carried to ideal levels (Özmete and Zubaroglu-Yanardag, 2016). Violence against women happens as something that has been accepted as normal when women are considered more traditional, the traditional perspective will consider women to be able to take it in stride, therefore increasing as women grow their rights.

Value, the second component of this research, include an individuals' feelings, thoughts, behaviors and attitudes. Many scientists in the field of social science have come to a consensus on the importance of value (Dilmaç, 2007). As a matter of fact, Value and attitudes go hand in hand. $b$ ecause our attitudes towards events are effective in solving problems related to behaviors. It is remarkable that the individual has gained or possessed the value? in the situation that causes these attitudes to occur. While the attitudes turn into behavior, cognitive, affective and behavioral effects become visible (Balc1, 2008). That said, value is more central than attitudes. With this aspect, value has a structure that determines the behaviors and attitudes of the individual (Demirhan İşcan, 2007). What is good and bad in a society, the way of thinking and behavior are shaped within the framework of value. This aspect of value works as a mechanism to provide social control and reward (Özensel, 2003). Values are the rules that help an individual to be consistent in his behavior, to direct those behaviors, to shape his personality and character. In short, the value preferred by the individual determine his / her behavior (Aydin, 2005). With globalization, the meanings and qualities of value have also changed. andnew values such as democracy, entrepreneurship and competition have emerged instead of traditional value (Gül, 2013). Value is a mechanism that both regulates an individual's behavior and evaluates the behaviors of other individuals (Sesli, 2014).

Studies with basic value orientations are encountered in the relevant literature. Relationship between life worth and personality traits of university students (Çalışkur, 2008), value orientations of teacher candidates (Sar1, 2005), secondary school students' value orientations (Sesli, 2014); the relationship between the autonomy levels of secondary school students and their value orientation (Sesli \& Demir Başaran, 2016) are some of these. There are also others in the relevant literature on value orientations of education faculty students (Bulut, 2012); the relationship between adolescents' value orientations and internet addiction (Doğan, 2018); the relationship between basic human value and life satisfaction (Öztürk \& Ünal, 2019); value orientations of classroom teacher candidates (Y1ldırım, 2020); value orientations of social work students (Acar, Akar, \& Acar, 2016); measurement of core worth (Demirutku \& Sümer, 2010); university students' value orientation and awareness to predict their happiness level (Kıliç, Yildız-Akyol, \& Yoncalık, 2018); value orientations of university students (Kıran, 2016). Öngen and Aytaç (2013) also discussed the relationship between university students' attitudes towards gender roles and life value in their study.

Although there are studies in the area of gender roles and literature, the interaction between the attitudes of university students towards gender roles and value to date has not been examined. Bearing in mind this research is conducted at university level with young people, it proves itself as important. This is because young people's experiences will be influenced by the effects of culture, value judgments and attitudes towards gender stereotypes that decide their attitudes towards male and female roles and social value orientations. It is understood that at this age, normalized perceptions and feelings would influence people's actions in the future. In this time, 
such roles which contribute to the normalization of gender inequality and the thinking that men are innately the superior side with authority, and women as the single individual in question, submissive to authority, compliant, feminine and awaited are shaped. With a view to making meaningful contributions to the field in light of this evidence, this research explored the variations between the attitudes of university students towards gender roles by gender and the degree to which their attitudes towards gender roles predict fundamental value orientations.

Answers to the following questions were sought within the context of this general intent.

(1) Is there a huge gap in the attitudes of university students regarding gender roles due to gender?

(2) How the attitudes of university students towards gender stereotypes forecast key value orientations?

\section{Method}

\section{Research Design}

The relational survey model, one of the descriptive survey models, was used in this research to investigate the association between attitudes and value orientations in university students with respect to gender roles. This model is a method of empirical analysis used to evaluate the interactions between more than one component, and examines the interaction between variables (Karasar, 2011).

\section{Study Group}

The population of this study is comprised of undergraduate students in a public university in Turkey and a private university in the Turkish Republic of Northern Cyprus during the academic year 2020-2021. Undergraduate students in a state university in Turkey and a private university in the Turkish Republic of Northern Cyprus during the academic year 2020-2021 constitute the universe of this research. The study sample consists of 252 undergraduate students in these two universities who were chosen using an appropriate sampling method. 169 participants are female (67.2 percent), while 83 are male (32.9 percent). After the Ethics Committee approved this study, written permission was obtained from the relevant institutions prior to the study's commencement.

\section{Data Collection Tools}

\section{Gender roles attitude scale}

It is a 5-point likert style measurement instrument created by Zeyneloğlu and Terzioğlu in 2011 to assess the gender identity attitudes of university students, which consists of 38 objects and graded between 0-5. Egalitarian gender roles, "female gender roles", "marriage gender roles", "traditional gender roles", and "male gender roles"; are the 5 sub-dimensions of the scale. "190" is the highest score and "38" on the scale is the lowest. The highest score received from the scale is inclusive against the student's gender roles; the lowest score reflects a conservative attitude. GRAS's Cronbach alpha coefficient was estimated to be .92 (Zeyneloğlu \& Terzioğlu, 2011). The Cronbach alpha reliability coefficient was estimated as .92 in this analysis as well. 


\section{Portrait Values Scale}

Schwartz, Melech, Lehmann, Burges, Harris and Owens (2001) created the scale to quantify core values which was later adapted to Turkish by Demirutku and Sümer (2010). There are 40 elements on the scale and a 6-point Likert style ranking was created for the assessment. There are 10 variables on the scale called control, performance, hedonism, arousal, selforientation, universalism, benevolence, culture, conformity, and security. Demirutku and Sümer (2010) reports, the coefficient of internal accuracy of Cronbach ranged from .61 to .84; they found that the coefficient of reliability of the test-retest ranged from .65 to .82 . The Portrait Values Scale reliability coefficient was estimated as .89 in this analysis.

\section{Data Analysis}

In the analysis of the results, the t-test was applied to variables displaying a normal distribution. Using Pearson product moment correlation, the relationship of variables to each other was studied. Later, multiple regression analysis was conducted based on this relationship to examine if the variables predicted each other and whether the statistical significance level of the results was agreed as $\mathrm{p}<.05$ if they were exhausted. By switching to the $25^{\text {th }}$ edition of the statistical application called SPSS, the collected data was prepared for review (Statistical Package for the Social Sciences).

\section{Findings}

\section{Findings related to the first research question}

Findings are shared on the gap between attitudes towards gender roles in university students according to gender. In terms of the gender dimension, university students' attitudes towards gender roles were analyzed. Table 1 gives the results of the t-test evaluation of gender identity attitude scale ratings.

Table 1. In terms of gender variable, t-test result for Gender Roles

\begin{tabular}{llclllll}
\hline Depended Variable & Gender & $\mathrm{n}$ & Mean & Std.Dev. & df & t & Sig. \\
\hline Gender Roles Attitude & Male & 83 & 121.93 & 27.343 & 250 & 7.523 & $.000 *$ \\
Scale Total Score & Female & 169 & 143.11 & 17.084 & & & \\
\hline
\end{tabular}

$$
* \mathrm{p}<.05
$$

The t-test was used to test the magnitude of the disparity between discrepancies when analyzing students' reactions to gender roles in terms of sex. According to the findings presented in Table 1 , the average attitude score for women towards gender roles was found to be higher than the attitude scores for men against gender roles $(\mathrm{t}=7.523, \mathrm{p}<.05)$.

\section{Findings of the relationship between university students' gender roles attitude scale and value orientations}

In order to see the relationship between the factors in the study and to add to evaluations of interpretations and regression analysis, correlation analysis is used. The relationship was analyzed using the Pearson Product Moment Association between the variables of attitudes towards gender roles and meaning orientations. Findings from the analysis are summarized in Table 2. 
Table 2. The relationship between attitudes towards gender roles and value orientations

\begin{tabular}{|c|c|c|c|c|c|c|c|c|}
\hline \multirow{2}{*}{ PVS (1) } & 1 & 2 & 3 & 4 & 5 & 6 & Mean & Std.Dev. \\
\hline & 1.000 & & & & & & 146.74 & 23.20 \\
\hline $\begin{array}{l}\text { Egalitarian Gender } \\
\text { Roles(2) }\end{array}$ & $.231^{* *}$ & 1.000 & & & & & 28.23 & 5.36 \\
\hline $\begin{array}{ll}\begin{array}{l}\text { Female } \\
\text { Roles (3) }\end{array} & \text { Gender }\end{array}$ & $.207^{* *}$ & $.699^{* * *}$ & 1.000 & & & & 23.80 & 4.62 \\
\hline $\begin{array}{l}\text { Marriage Gender } \\
\text { Roles(4) }\end{array}$ & $.224^{* *}$ & $.739^{* * *}$ & $.743^{* * *}$ & 1.000 & & & 25.36 & 4.97 \\
\hline $\begin{array}{l}\text { Traditional Gender } \\
\text { Role (5) }\end{array}$ & $.389^{* *}$ & $.513^{* *}$ & $.483^{* *}$ & $.567^{* *}$ & 1.000 & & 27.30 & 5.31 \\
\hline $\begin{array}{l}\text { Male Gender Role } \\
\text { (6) }\end{array}$ & $.237^{* *}$ & $.647^{* * *}$ & $.596^{* * *}$ & $.651^{* *}$ & $.562^{* *}$ & 1.000 & 7.14 & 1.49 \\
\hline
\end{tabular}

Portrait Values Scale (PVS)

A statistically important association between the attitude subscales about gender roles and meaning orientations was observed in view of the results in Table 2 . The female gender roles $(\mathrm{r}=.20, \mathrm{p}<.01)$, marriage gender roles $(\mathrm{r}=.22, \mathrm{p}<.01)$, traditional gender roles $(\mathrm{r}=.38, \mathrm{p}<.01)$, male gender roles $(\mathrm{r}=.23, \mathrm{p}<.01)$ are associated positively with the orientation of value.

\section{Findings related to the third research question}

Findings as to whether university students' gender stereotypes are a major indicator of levels of value orientation are shared. Using multiple regression analysis, the results on university students' attitudes towards gender roles to predict their value orientation were obtained and summarized in Table 3.

Table 3. Multiple Regression Analysis Results on the Prediction of Attitude Scores Regarding Gender Roles

\begin{tabular}{|c|c|c|c|c|c|}
\hline Model & Unstandardized B & $\begin{array}{l}\text { Coefficients } \\
\text { Std. Error } \\
\end{array}$ & $\begin{array}{l}\text { Standardized } \\
\text { coefficients Beta }\end{array}$ & $\mathrm{t}$ & sig \\
\hline (Constant) & 97.087 & 8.097 & & 11.991 & .000 \\
\hline $\begin{array}{l}\text { Egalitarian Gender } \\
\text { Roles }\end{array}$ & .045 & .461 & .010 & .098 & .922 \\
\hline Female Gender Roles & 67 & .480 & .013 & .139 & .890 \\
\hline Marriage Gender Roles & .338 & .544 & .073 & .621 & .535 \\
\hline $\begin{array}{l}\text { Traditional Gender } \\
\text { Role }\end{array}$ & 1.577 & .401 & .362 & 3.930 & .000 \\
\hline Male Gender Roles & -.677 & 1.417 & -.044 & -.478 & .633 \\
\hline
\end{tabular}

In Table 3, the dependent variable (predicted variable) with the cumulative score of the questionnaire on portrait values and the independent variables can be found. Egalitarian gender roles, female gender roles, gender factor of marriage, traditional gender roles, entering approach with male gender roles scores used in multiple linear regression analysis. $16 \%$ percent was the number of independent variables describing the dependent variable. Statistically, the 'traditional gender roles' sub-dimension scores were found to be relevant $\left(\mathrm{R}=.404, \mathrm{R}^{2}=.163, \mathrm{p}<.001\right)$ according to the standardized regression coefficient. The variable that has the most impact on value orientations is traditional gender roles $(\mathrm{t}=3.93, \mathrm{p}<.05)$. It was determined that the variables equal gender role, role of female gender roles, marital gender roles factor, traditional gender roles, role of male gender roles were not significant. 


\section{Discussion, Conclusion and Suggestions}

This research explored the differences in the perceptions of university students toward gender roles. The association between attitudes to gender roles and values and the degree to which individual attitudes to gender roles predicted fundamental values were studied. In accordance with the literature the conclusions obtained from the mathematical study are discussed and interpreted.

In view of the research, gender attitudes vary greatly according to gender; it was observed that the degree of egalitarianism of female students is far higher than male students. We may assume that the outcomes of the current research are in line with the findings from the literature and their inclusive attitudes towards gender are strong because of the high level of education of university students (asa is the case in the studies of Alptekin, 2019; Aş111, 2001; Aydın, Özen, Y1lmaz, \& Sungur, 2016; Croft, Atkinson, Sandstrom, Aknin, \& Orbell, 2020; Daşl1, 2019; Geçici et al., 2017; Gui, 2019; Güzel, 2016; Hunter, Guernsey de Zapien, Papenfuss, Fernandez, Meister, \& Giuliano, 2004; Kantoğlu, 2017; Kaplan, 2016; Kimberly \& Mahaffy, 2002; Öngen \& Aytaç 2013; Özden \& Gölbaş1, 2018; Özpulat \& Özvarış, 2019; Seçgin \& Tural 2011; Seven, 2019; Takkin, 2020; Vega, Rico, \& Fernández, 2017; Zuo, Lou, Gao, Lian, \& Shah, 2018). It is understandable that the feminist mindset of women is stronger than that of men in a society where women's effectiveness in social life has increased in recent years. Furthermore, while there are some gender-specific traits, society is one of the key variables that decide individuals' gender roles and attitudes. The roles and models are established by society for females and males, however, these can shift over time. It was concluded that female students were more feminist, and more stereotypical gender views were followed by male students, according to the findings of the report. It can be thought, from this point of view, that as they become mothers in the future, the understanding of female teenagers in terms of gender and their appraisal of the process with an inclusive viewpoint can lead to both their own personality formation and their child-rearing attitudes. It is crucial for parents to adopt a democratic attitude, when raising their children, which is influential in establishing equal gender roles, especially for male students.

Another research result is that the association between attitude subscales against gender stereotypes and meaning orientations is statistically favourable. A research finding in the literature confirms this (Öngen and Aytaç, 2016). They found a strong and important association between the life values component of students and the sub-dimensions of gender interpretation, "egalitarian gender role" and "gender role in marriage" in a study they conducted with university students. Women and men have different social statuses, and the position of men is higher than that of women. Society's coercive acts stress the individual to behave in line with the social position he/she has (Eagly, 1983). Equal positions that society gives to men and women; is defined as the equal sharing of responsibilities between men and women in family, working, marriage and education life (Hunter et al., 2004). Although traditional norms and cultural values still have an effect on women and men in our society, it is not overlooked that there is a change in these norms. It is observed that men and women view changing norms in a different fashion and they mostly display attitudes in favour of their own gender group (Seçgin \& Tural, 2011). The relation between the attitude to gender norms and the sub-dimension and value orientations of "traditional gender role" was found to be positively important. Explanatory awareness of the value orientation of university students towards "traditional gender role" is very strong. In this sense, the traditional definition of gender becomes an important mind-set that needs to be discussed. To put it in another way, the importance of the gender concept appears in this context. It is assumed that related prevention activities for teens, who are the adults of the future, must be carried out now, as violence against women is rising. 
Another research result is that the association between meaning orientations and the subdimension of 'traditional gender role,' which is one of the attitudes towards sub-scales of gender norms, was positively important. The assumption that women act in accordance with the values associated with traditional concepts of femininity and men with traditional masculine concepts may clarify the distinction of women and men in these value orientations, taking into account the positions assigned to men and women by society (Vogel, Wester, Heesacker, \& Madon, 2003). In stud conducted with university students addressing traditional gender roles tendencies according to gender the results show that female students perceive gender roles in an egalitarian structure and that male students perceive gender roles more traditionally support the findings of the present study (Croft et al., 2020; Daşl1, 2019; Geçici et al., 2017; Kaplan, 2016; Öngen \& Aytaç 2013; Trommsdorff \& VeIwawaki, 1989; Vega, Rico, \& Fernández, 2017). In their study Kimberly and Mahaffy (2002), to assess the traditional and non-traditional views of university students about gender roles, they determined that traditional gender roles were accepted by students. It is possible that the finding that men and women follow the traditional gender model rather than the feminist gender role, which expresses equal distribution of tasks and obligations in everyday life, comes from a patriarchal viewpoint in which women's dominant roles are passive and inactive, whereas men's dominant roles are effective and their acceptance as the leader of the family isvalid.

University students display a reasonably egalitarian approach towards gender stereotypes in Zuo et al. (2018). They want girls to be fairer than boys in social standing and in the distribution of wealth. In this way, the value decisions of society will exert emphasis on male and female roles. In the inclusive approach to gender, it is recognized that there is no sharp difference between women and men assuming equal obligations and positions in personal, professional, marital, social and educational life (Akın \& Demirel, 2003). Farooq and Tong Kai (2017) published a descriptive report that comprehensively analyzes the actual condition of female teachers serving in Pakistan's primary schools. In providing female teachers with inadequate resources for advancement, there are disparities and inadequacies. Female teachers are recommended to develop their expertise in the education sector and in the school environment, to have fair opportunity, to make appointments clear and to encourage procedures.

Numerous new experiments are being conducted that have the potential to have a multiplicity of effects on the gender dimension, including increasing women's participation in society and public roles. To increase cultural awareness, a number of additional research projects could be directed toward increasing people's awareness of social issues. What's particularly valuable for the groups of people they're also expected to serve is the opportunity to discover a role in the field of mental health care, which could benefit both counsellors and applicants in this field. Expanding on university curricula to eliminate gender inequity may be recommended for students to be on gender identity in relation to gender. New findings regarding students' value orientation beliefs are made. Among these are some intriguing findings regarding their contributions to social science and utility, as well as their relationships between values. Additionally, a greater proportion of gender-related courses should be added to university curricula to aid in the process of expansion and advancement.

There are certain drawbacks to this analysis. In this research, students from two separate universities were approached in order to explore university students' perceptions and meaning orientations towards gender roles. It is important to restrict the generalization of these research findings to the students enrolled in these schools. It is proposed that new research exploring the value system of parents and young people should be performed based on the results of this report, in which the value judgments of young people are investigated in terms of various 
variables.

On the other hand, this study has some limitations. The research is limited to the scales that are used in this analysis. In experiments to be carried out on gender preferences, using the interview approach, one of the qualitative testing approaches, could be recommended to explore the subject more comprehensively. Working with students from different levels of education, with different variables, and students from different age groups may be suggested in new studies to be carried out on this subject.

\section{Acknowledgments}

This article is based on a master's thesis conducted under the direction of the second author by the first author in the area of Guidance and Psychological Counselling at the European University of Lefke Institute of Graduate Studies and Research.

\section{References}

Acar, H., Akar, M., \& Acar, Y. B. (2016). Sosyal hizmet öğrencilerinin değer yönelimleri [Value tendencies of social work students]. Kastamonu Education Journal, 24(1), 97118.

Akın, A., \& Demirel, S. (2003). Toplumsal cinsiyet kavramı ve sağlığa etkileri [The concept of gender and its effects on health]. Cumhuriyet Medical Journal, 25(4), 73-82.

Alptekin, B. (2019). Öğretmen adaylarının toplumsal cinsiyet rolleri ile öğretmenlik mesle ğine yönelik tutumlarl [Pre-service teachers' attitudes towards gender roles and teaching profession] (Unpublished master's thesis). Bolu Abant İzzet Baysal Üniversitesi, Bolu.

Altınova, H. H., \& Duyan, V. (2013). Toplumsal cinsiyet algısı ölçeğinin geçerlik güvenirlik çalışması [The validity and reliability of perception of gender scale]. Society and Social Work, 24(2), 9-22.

Aş1l, G. (2001). Üniversite öğrencilerinin cinsiyet rolleri ve ego (ben) durumları arasındaki ilişkisi [The relationship of university student's gender role's and ego state']. (Unpublished master's thesis). Selçuk University, Konya.

Aydın, M., Özen, B. E., Yılmaz, G. Ş., \& Sungur, M. A. (2016). Attitudes of nursing students regarding to gender roles. AIBU Journal of Social Sciences, 16(1), 223-242.

Aydın, A. (2005). Dil-tarih ve coğrafya fakültesi ögrrencilerinin değer hiyerarşileri ile ilahiyat fakültesi öğrencilerinin değer hiyararşilerinin karşılaştırılması [Compairs value hiyerarchy between the students language and history-geography faculty and the student of divinity facult]. (Unpublished master's thesis). Ankara University, Ankara.

Baki, L. (2019). Toplumsal cinsiyet ve feminizm bağlamında 'femvertising': Kadın imgesi üzerine bir araştırma [Femvertising in the context of gender and feminism: A research on female image]. (Unpublished master's thesis). Marmara University, Istanbul.

Balc1, N. (2008). Illköğretim 6. sinıf sosyal bilgiler dersinde değer ĕgitiminin etkililiği [Effectiveness of value education on social studies lesson for 6 grade primary school]. (Unpublished master's thesis). Marmara University, Istanbul.

Batga, B. (2014). Toplumsal cinsiyet rolleri ile bu rollerin yaşam dengesine olan etkisi: Özel sektörde bir araştırma [Social gender roles and impact of these roles on work life balance: A research in private sector]. (Unpublished master's thesis). Dokuz Eylül University, İzmir

Buğra, A. (2015). Sosyal politika ve toplumsal cinsiyet çalışmaları: Verimli bir birliktelik [Social policy and gender studies: a fruitful partnership]. (Compiled: Saniye Dedeoğlu 
and Adem Y. Elveren), 2000'ler Türkiye'sinde sosyal politika ve toplumsal cinsiyet [During the 2000s, social policy and gender in Turkey]. Ankara: İmge Publisher, 13-22.

Bulut, S. S. (2012). Gazi eğitim fakültesi öğrencilerinin değer yönelimleri [Value tendencies of the students at the college of education of Gazi University]. International Journal of Turkish Literature Culture Education, 1(3), 216-238.

Bussey, K., \& Bandura, A. (1999). Social cognitive theory of gender development and differentiation. Psychological Review, 106(4), 676-713.

Croft, A., Atkinson, C., Sandstrom, G., Aknin, L., \& Orbell, S. (2020). Loosening the GRIP (Gender Roles Inhibiting Prosociality) to Promote Gender Equality. Personality and Social Psychology Review, 25(1),66-92. https://doi.org/10.1177/1088868320964615

Connell, R. W. (2016). Toplumsal cinsiyet ve iktidar [Gender and power in society], (Trans: Cem Soydemir), İstanbul: Ayrıntı Publications.

Çıtak A. (2008). Kadınların çalışmasına yönelik tutum: Cinsiyet, cinsiyet rolü ve sosyoekonomik düzeye göre bir karşılaştırma [Attitude towards woman's working: A comparison according to sex, gender role and socioeconomic status]. (Unpublished master's thesis). Ankara University, Ankara.

Çalışkur, A., \& Aslan, A. E. (2013). Rokeach değerler envanteri güvenirlik ve geçerlik çalışması [Rokeach values inventory reliability and validity study]. Balıkesir University The Journal of Social Sciences Institute, 16(29), 81-105.

Daşl1, Y. (2019). Öğrencilerin toplumsal cinsiyet rollerine ilişkin tutumlarının belirlenmesi üzerine bir alan araştırması [A field study on determining the attitudes of students on gender roles]. YYU Journal of Education Faculty, 16(1), 364-385.

Deaux, K., \& Major, B. (1987). Putting gender into context: An interactive model of gender related behavior. Psychological Review, 94(3), 369-389.

Deikman, A. B., Eagly, A. H., \& Kulesa, P. (2002). Accuracy and bias in stereotypes about the social and political attitudes of women and man. Journal of Experimental Social Psychology,38, 268-282.

Demirhan İşcan, C. (2007). İlköğretim düzeyinde değerler eğitimi programının etkililiği [The efficiency of primary school values education curriculum]. (Unpublished doctoral dissertation). Hacettepe University, Ankara.

Demirutku, K., \& Sümer, N. (2010). Temel değerlerin ölçümü: Portre değerler anketinin Türkçe uyarlamas1 [The measurement of basic values: Turkish adaptation of portrait values questionnaire]. Turkish Psychological Articles, 13(25), 17-25.

Dilmaç, B. (2007). Bir grup fen lisesi ögrencisine verilen insani değerler eğitiminin insani değerler ölçeği ile sinanması [The assesment of the teaching of humane values which are imposed a group of science high school students by humane values scale]. (Unpublished doctoral dissertation). Selçuk University, Konya.

Doğan, M. (2018). Ergenlerin değer yönelimleri ve değer yönelimlerinin internet bağımlılığıyla ilişkisinin incelenmesi [Investigation of the value tendencies of adolescents and the relation between value tendencies and internet addiction]. International Journal of Social and Educational Sciences, 5(10), 263-285.

Dökmen Z. Y. (2018). Toplumsal cinsiyet-sosyal psikolojik açıklamalar [Gender-Social Psychological Explanations]. Ankara: Remzi Kitabevi.

Dulin, A. M. (2007). A lesson on social ole theory: An example of human behavior in the social environment theory. Advanced in Social Work, 8(1), 104-112.

Dursun, A. (2020). Kadına yönelik şiddet: ergenlerin toplumsal cinsiyet algılarının yordayıcılığ1 [Violence against women: The predictive of adolescents' perceptions of gender]. Turkey Journal of Integrative Psychotherapy, 3(6), 33-44.

Eagly, A. H. (1983). Gender and social influence: A social psychological analysis. American Psychologist, 38(9), 971-981. 
Farooq, M. S., \& Tong Kai, Y. (2017). Female teacher problems at primary level in Pakistan Administered Kashmir. International Online Journal of Primary Education, 6(1), 1925.

Geçici, F., Göllüce, A., Güvenç, E., \& Çelik, S. (2017). Üniversite öğrencilerinin toplumsal cinsiyet rollerine ilişkin tutumları [The attitudes of the university students' regarding the gender roles]. Süleyman Demirel University Journal of Health Sciences, 8(1), 2127.

Giddens, A. (2008). Sosyoloji [Sociology]. (Trans.: İsmail Y1lmaz), İstanbul: Red Publications. Gui, Y. (2019). Gender role attitudes and their psychological effects on Chinese youth. Social Behavior and Personality: an international journal (SBP Journal), 47(5),1-8. doi: https://doi.org/10.2224/sbp.7563

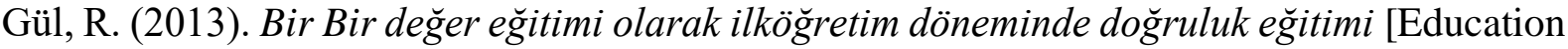
of honesty as a value education during a primary education]. (Unpublished master's thesis). Hitit University, Çorum.

Gümüşoğlu, F. (2008). Ders kitaplarında toplumsal cinsiyet [Gender in school text books]. Society and Democracy, 2(4), 39-50.

Güzel A. (2016). Öğrencilerin toplumsal cinsiyet rolleri tutumları ve ilişkili faktörler [Gender roles attitudes of unıversity students and related factors]. Gümüşhane University Journal of Health Sciences, 5(4),1-11.

Hunter, J. B., Guernsey de Zapien, J., Papenfuss, M., Fernandez, M. L., Meister, J., \& Giuliano, A. R. (2004). The impact of a promotora on increasing routine chronic disease prevention among women aged 40 and older at the U.S.-Mexico Border. Health Education Behaviour, 31, 18-27.

İmamoğlu, S. (2008). Genç yetişkinlikte kişilerarası ilişkilerin cinsiyet, cinsiyet rolleri ve yalnızlık algısı açısından incelenmesi [Examination of interpersonal relationships in young adulthood in terms of gender, sex-role, and loneliness]. (Unpublished doctoral dissertation). Marmara University, Istanbul.

Kaçar, Ö. (2007). Toplumsal cinsiyet ve kadının konumu: Türkiye'de yakın zamanlardaki değişimi anlamak [Social gender and the position of woman: Understanding of the recent changes in Turkey]. (Unpublished master's thesis). Afyon Kocatepe University, Afyon.

Kalaycı, N., \& Hayırsever, F. (2014). Toplumsal cinsiyet eşitliği bağlamında vatandaşlık ve demokrasi eğitimi ders kitabına yönelik bir inceleme ve bu konuya ilişkin öğrenci algilarının belirlenmesi [An analysis of citizenship and democracy education text book in the context of gender equality and determining students' perceptions on gender equality]. Educational Sciences: Theory \& Practice,14(3),1-26. DOI: 10.12738/estp.2014.3.1813

Kantoğlu, A. (2017). Bir grup ergenin toplumsal cinsiyet algllarının sosyodemografik özelliklere göre değerlendirilmesi [The effect of social demographic factors on the perception of the genderrole: an in depth study performed on adolescents]. (Unpublished master's thesis). Iş1k University, İstanbul.

Kaplan, K. (2016). Evli bireylerde toplumsal cinsiyet rollerine ilişkin tutumların, evlilik doyumuna ve psikolojik iyi olus durumuna etkisinin incelenmesi [An investigation of the attitude of married individuals towards social gender roles and its effects on the marriage satisfaction and psychological well-being]. (Unpublished master's thesis). Beykent University, İstanbul

Kaplan, V. (2019). Kişilerarası ilişkisel rol analizi'nin hemşirelik öğrencilerinin anksiyete düzeylerine, toplumsal cinsiyet rol tutumlarına ve kişilerarası problem çözme yönelimlerine etkisi [The effect of interpersonal relational role analysis on nursing 
students' anxiety levels, gender role attitudes and interpersonal problem solving orientation]. (Unpublished doctoral dissertation). Ankara University, Ankara.

Karakılıç, M., Alay, S., \& Koçak, S. (2008). Kadın ve yönetici: Aday yöneticiler yönetimsel becerilerde cinsiyete özgü kalıplara sahip midirler? [Woman and manager: Do cadet sport managers have gender-role stereotypes with respect to some managerial skills?]. Hacettepe J. of Sport Sciences, 19(4), 220-237.

Karasar, N. (2011). Bilimsel araştırma yöntemleri [Scientific research methods]. Ankara: Nobel Publishing.

Keskin, F., \& Ulusan, A. (2016). Kadının toplumsal inşasına yönelik kuramsal yaklaşımlara dair bir değerlendirme [The evaluation on the theoretical approaches related to social construction of women]. The Journal of Akdeniz University's Faculty of Communication, 26, 47-68.

Kimberly, A., \& Mahaffy, K. (2002). The gendering of adolescents' childbearing and educational plans: reciprocal effects and the influence of social context. Sex Roles, 11(12), 403-417.

Kıran, Ö. (2016). Üniversite öğrencilerinin değer yönelimleri (OMÜ Örneği) [University students value trends (OMU Sample)]. Journal of International Social Research, 9(43), 1266-1272.

Kılıç, S., Yıldız-Akyol, E., \& Yoncalık, O. (2018). Üniversite öğrencilerinin değer yönelimleri ve farkındalıklarının mutluluk düzeylerini yordaması [Values and mindfulness among university students in the prediction of happiness]. The Journal of Happiness \& WellBeing, 6(1), 49-60.

Lagrave, R. M. (1992). Denetimli bir özgürleşme [A controlled emancipation]. G. Duby, \& M. Perrot, in, Kadınların tarihi 5-yirminci yüzyılda kültürel bir kimliğe doğru [Women's history towards a cultural identity in the 5th-twentieth century]. (Trans.A. Fethi, 419451). İstanbul: Türkiye İş Bankası Publications.

Krahe, B. (2018). Violence against women. Current Opinion in Psychology, 19, 6-10.

Öngen, B., \& Aytaç, S. (2013). Üniversite öğrencilerinin toplumsal cinsiyet rollerine ilişkin tutumları ve yaşam değerleri ilişkisi [Attitudes of university students regarding to gender roles and relationship with life values]. Sociology Conferences, 48(2), 1-18.

Özden S., \& Gölbaşı Z. (2018). Sağlık çalışanlarının toplumsal cinsiyet rollerine ilişkin tutumlarının belirlenmesi [Determination of health workers' attitudes towards gender roles]. Kocaeli University Journal of Health Science, 4(3), 95-100. doi:10.30934/kusbed.420223

Özensel, E. (2003). Sosyolojik bir olgu olarak değer [The sociological relevance of values]. Journal of Values Education,1(3),217-239.

Özmete, E., \& Zubaroğlu Yanardağ, M. (2016). Erkeklerin bakış açısıyla toplumsal cinsiyet rolleri: Kadın ve erkek olmanın değeri [The male perspectıve on gender roles: The value of being a male or a female]. Turkish Journal of Social Research, 20(1),91-107.

Özpulat, F., \& Özvarış, Ş. B. (2019). Akşehir sağlık yüksekokulu öğrencilerinin özyeterlilik düzeyleri ve toplumsal cinsiyet algılarının belirlenmesi [The determination of the selfefficacy levels and gender perception among the students of the akşehir school of health]. Journal of Continuing Medical Education,28(2), 98-107. DOI: $10.17942 /$ sted.431011

Öztürk, M., \& Ünal,V. (2019). Temel İnsani değerler ile yaşam doyumu arasındaki ilişki: Sivas Cumhuriyet Üniversitesi örneği [A relation between basic human values and life satisfaction: The case of Sivas Cumhuriyet University]. Hacettepe University Journal of Faculty of Letters, 36(1), 61-74.

Ridgeway, C. L., \& Smith-Lovin, L. (1999). The gender system and interaction. Annual Review of Sociology, 25,191-216. 
Sarı, E. (2005). Öğretmen adaylarının değer tercihleri: Giresun Eğitim Fakültesi örneği [Value preferences of prospective teachers: A case of Giresun Faculty of Education]. Journal of Values Education-Turkey, 3(10), 73-88.

Schmitt, D. P. (2003). Are man universally more dismissing than women? Gender differences in romantic attachment across 62 cultural regions. Personal Relationships, 10(3), 307331.

Schroeder, K. M., Bamaca-Colbert, M. Y., \& Robins, R. W. (2019). Becoming more egalitarian: A longitudinal examination of Mexican-origin adolescents' gender role attitudes. Developmental Psychology, 55(11), 2311-2323.

Schwartz, S. H., Melech, G., Lehmann, A., Burgess, S., Harris, M., \& Owens, V. (2001). Extending the cross-cultural validity of the theory of basic human values with a different method of measurement. Journal of cross-cultural psychology, 32(5), 519-542.

Scott, J. W. (2007). Toplumsal cinsiyet: Faydalı bir tarihsel analiz kategorisi [Gender: A useful category of historical analysis] (Trans.: Aydın Tunç Kılıç), İstanbul: Agora Kitaplığı.

Seçgin, F. (2012). Sosyal bilgiler dersinde toplumsal cinsiyet etkinliklerinin ögrencilerin algı ve tutumlarina etkisi [The effect of gender activities in social studies lesson on the perception and attitude of the primary education students]. (Unpublished doctoral dissertation). Gazi University, Ankara.

Seçgin, F., \& Tural, A. (2011). Sınıf öğretmenliği bölümü öğretmen adaylarının toplumsal cinsiyet rollerine ilişkin tutumları [Attitudes on gender roles of primary school teacher candidates]. Education Sciences, 6(4), 2446-2458.

Sesli, Ç. (2014). Ortä̈ğretim öğrencilerinin özerklik düzeyleri ile değer yönelimleri ve kendini ayarlama düzeyleri arasındaki ilişkinin incelenmesi [The relation between autonomy levels and value tendency and self monitoring levels of secondary school students]. (Unpublished master's thesis). Erciyes University, Kayseri.

Sesli, Ç., \& Demir Başaran, S. (2016). Ortaöğretim öğrencilerinin değer yönelimleri ve özerklik düzeyleri arasındaki ilişkinin incelenmesi [The relation between value tendency and autonomy levels of high school students]. Mustafa Kemal University Journal of Social Sciences Institute, 13(34), 238-258.

Seven, N. (2019). Üniversite öğrencilerinin toplumsal cinsiyet rollerine ilişkin tutumları [The attitudes of university students on social gender roles]. PESA International journal of social studies, 5(2), 134-149.

Şimşek, H. (2011). Toplumsal cinsiyet eşitsizliğinin kadın üreme sağlı̆̆ına etkisi:Türkiye Örneği [Effects of gender inequalities on women's reproductive health: The case of Turkey]. Journal of Dokuz Eylul University Medical Faculty, 25(2), 119-126.

Takkin, T. (2020). Üniversite öğrencilerinin toplumsal cinsiyet tutumlarının özgüven, kişilik özellikleri ve sosyo-demografik değişkenler ile ilişkisinin incelenmesi [An examination of the relationship between social gender attitudes with self-confidence, personality characteristics and socio-demographic variables of university students]. (Unpublished master's thesis). Çağ University, Istanbul.

Vega, E. G., Rico, R., \& Fernández, P. (2017). Sex, gender roles and sexual attitudes in university students [sexo, roles de género y actitudes sexuales en estudiantes universitarios]. Psicothema, 29(2), 178-183.

Vogel, D. L., Wester, S. R., Heesacker, M., \& Madon, S. (2003). Conforming gender stereotypes: A social role perspective. Sex Roles, 48(11), 519-528.

Wood, W., \& Eagly, A. H. (1999). The origins of sex differences in human behavior: Evolved dispositions versus social roles. American Psychologist, 54(6), 408-423.

Yapıcıoğlu Ayaz, Y., Kıvanççı, G., \& Safarov, A. (2019). Psikanalitik kuram ve reklamda yaratıcılik [Psychoanalytical theory and creativity in advertising]. The Fourth Power, 2(2), 75-92. 
Yıldırım, E. (2020). Sınıf öğretmeni adaylarının değer yönelimleri: bir durum çalışması [Value Aspects of Pre-Service Elementary Teachers: A Case Study]. Kilis 7 Aralık University Journal of Social Sciences, 10(19), 109-126.

Zeyneloğlu, S. (2008). Ankara'da hemşirelik öğrenimi gören üniversite öğrencilerinin toplumsal cinsiyet rollerine ilişkin tutumlar [Attitudes of nursing students enrolled at universities in Ankara towards gender roles]. (Unpublished doctoral dissertation). Hacettepe University, Ankara.

Zeyneloğlu, S., \& Terzioğlu, F. (2011). Toplumsal cinsiyet rolleri tutum ölçeğinin geliştirilmesi ve psikometrik özellikleri [Development and psychometric properties gender roles attitude scale]. H. U. Journal of Education, 40, 409-420.

Zuo, X., Lou, C., Gao, E., Lian, Q., \& Shah, I. H. (2018). Gender role attitudes, awareness and experiences of non-consensual sex among university students in Shanghai, China. Reproductive Health, 15(1), 1-10. 